\title{
Women and Crime in the Rural-Urban Fringe
}

\author{
Dr. Barbara A. Rockell \\ Associate Professor \\ Department of Sociology \\ St. John Fisher College \\ 3690 East Avenue \\ Rochester, NY 14618
}

Contact - Barbara A. Rockell: brockell@ @jfc.edu; 0015853852134

\begin{abstract}
This article focuses on human actors and a spatial setting which are rarely the subject of criminological inquiry. Both the actors (drug-involved low-level female offenders) and the setting in which they reside (the rural-urban fringe) have been relegated to some nether world of criminal justice scholarship: they are considered neither significant nor consequential enough to warrant scientific interest, and when they do enter the scholarly picture it is often in a caricaturelike way. Indeed, the women of interest here, drug-involved recidivist property and public order offenders, often have been reduced in the media to drug-addled, crystal-meth scarred beings with minimal voice, little context, and even less meaning, inhabiting a world that is defined simply for what it is not - neither urban, nor rural. The research took place in four upstate New York counties, with data collected by way of intensive, qualitative interviews from four sources: the Sheriffs in each county, other law enforcement personnel (including members of the road patrol and drug task forces for the county), jail staff, and 20 women being held in local county jails who met the selection criteria. In framing the inquiry, emphasis was placed on exploring the effects of the rural-urban fringe setting on the women's entry into drug / criminal activity and the roles played by community institutions, arrangements, and opportunity structures to facilitate their involvement in these pursuits.
\end{abstract}

Keywords: Drug-involved Rural Women; Rural Women Drug Use; Rural Women and Crime; Rural Gender Roles; Rural Domestic Violence 


\section{Introduction}

This article focuses on human actors and a spatial setting which are rarely the subject of criminological inquiry. Both the actors (low-level female offenders) and the setting in which they reside (the rural-urban fringe) have been relegated to some nether world of criminal justice scholarship: they are considered neither significant nor consequential enough to warrant scientific interest and when they do enter the scholarly picture it is often in a media-driven caricature-like way (Barkan \& Bryjak, 2009). Indeed, more often than not, these women of "the fringe," who have withstood the tremendous repercussions of economic and social change in their communities over the past decades, are reduced to drug-addled, crystal-meth scarred beings with minimal voice, little context, and even less meaning, inhabiting a world that is defined simply for what it is not - neither urban, nor rural.

This was the author's first entry into this world and the initial research questions considered were generated by a previous work (Rockell, 2008). Those questions related to claims made by urban female offenders about their criminal involvements in rural areas adjacent to their city of residence, including assertions of drug sales, larcenies, and prostitution. Their claims relating to larcenies and prostitution were substantiated by study respondents: suburban malls and large chain stores encouraged the former and a sex worker's relocation from a city to a rural male customer's residence for at least a while was not that unusual. Assertions about the urban women's involvement in drug sales did not ring true, however; they had said that they traveled to outlying towns to sell drugs for safety reasons -- they did not want to step on the toes of male drug sellers in the city. And, on a more enterprising note, the women also claimed that they could make more money in these areas because rural residents were less aware of drug prices and quality. Study respondents did not confirm the dominant presence of urban women in the rural drug scene, which appeared to remain male-controlled.

Rather than explore these issues further, a series of more intriguing, relatively unexplored issues emerged early on in the research, providing the primary focus and framework for the study presented here. That focus was drug-involved women living in the rural-urban fringe who engage in repetitive low-level property, public order, and drug crimes. And, in framing the inquiry, emphasis was placed on exploring the effects of that setting on their entry into drug/criminal activity and the roles played by community institutions, arrangements, and opportunity structures to facilitate their involvement in these pursuits.

The need for studies in this particular context cannot be overstated. Although criminological research is not as male-centered as it once was, it continues on an urban-centric track, resulting in a myopia usually justified by the historically dominant discourse about the "crime problem" in this country. Indeed, as Wells and Weisheit (2004: 1) observe, although there is "a growing interest in rural crime, it remains an understudied issue." Even more unexamined, according to these same authors, are the ecological factors in non-urban areas associated with 
criminal activity, an omission they call surprising given "the centrality of the concept of community in most rural research" (1).

Donnermeyer, Jobes, and Barclay (2006, p. 211) echo these concerns and propose that studies of crime in rural areas be grounded conceptually in the notion of community and framed analytically in place-based criminological theory or social disorganization theory. Such an approach enables, they argue, an understanding of how personal experiences or issues such as crime are shaped and a "part of a larger set of economic and social structural factors related to a globalizing economy, the ubiquitous influence of mass media, and growing interdependence of rural and urban areas" (p. 201). As will be seen, this approach is particularly relevant to making sense of the findings of this study where place, coupled with gender, definitely matters in how crime and drug use are accomplished and expressed.

\section{Definitional Issues}

The present research was conducted in four upstate New York counties. These counties are contiguous to Monroe County and a part of the Rochester, New York Metropolitan Statistical Area, an area with an estimated 2010 population of 1,054, 000. It is difficult to classify or define the counties of interest here and they have been called a variety of names by scholars and policymakers over time, depending on both disciplinary orientation and analytical approach, as well as the areas / residents to which / whom they are compared. For example, in their comprehensive review of the rural-urban fringe concept, Sharp and Clark (2008) observe that in the early $20^{\text {th }}$ century, names for these non-urban, once-agricultural areas bordering a city included "rurban" and the "rural-urban fringe," and how following suburbanization in the second half of the century, they became known as "penurbia," the "periurban region," and "exurbia."

Of even greater import, however, is what the previously cited authors say about early and contemporary scholarship concerning the fringe and its inhabitants. Sharp and Clark (2008, p. 62) first note that the "study of the rural / urban fringe has received modest attention from urban and community sociologists" and that a significant factor limiting its study is that the area is deemed "too urban to attract traditional researchers and too rural to incite urban scholarly inquiry." Moreover, they continue, the direction of research seems to have been mired in answering questions about how to classify these areas or what to consider them - whether they are "an early manifestation of the suburbs [i.e., simply suburbs of suburbs] or a distinct settlement form" (p. 63). Based on their own analysis of demographic data inclusive of numerous ecological, occupational, and sociocultural attributes relating to urban / suburban areas and rural areas of Ohio, these researchers conclude the latter or that the fringe is "distinct from the suburb, with more modest differences compared to more rural places” (p. 61).

The present study will not contribute to this discussion of where to place the rural-urban fringe on the classic rural / urban continuum. Instead, it is in agreement with Sharp and Clark (see discussion below), as well as Donnermeyer and his colleagues (2006, p. 205), who abandon 
the notion of "treating rural areas as a type of homogenous residual" and recognize that such ideal sociological types are less relevant in explaining crime patterns in the modern context of increased population mobility and interdependence between city and country. In other words, implicit in their argument is the assumption that an area like the rural-urban fringe is either more or less rural, depending on its "mix of exogenous and endogenous cultural, demographic, economic, and social forces" (p. 205).

\section{Study Parameters}

\section{Context $^{1}$}

As stated, this research took place in four upstate New York counties considered a part of the Rochester New York Statistical Area. And, it is clear to this author, based on lengthy discussions and a review of available demographic data, that these areas, despite some differences from each other, could be considered reflective of the rural-urban fringe. They appeared, in other words, to be far more rural than suburban on numerous demographic and ecological variables. Each consisted of many small communities with next to no manufacturing. They housed few / no shopping centers and their largest industry had remained agriculture or cottage industries related to it, plus the processing of its products. Residents often traveled into Rochester for work (although this had become less so in recent years) and a good number of them also had jobs in the four prisons sited in their communities or the large State and very wealthy private colleges located in their main towns.

The population of these counties was between 90-95 percent white. Residents had lower median incomes than the statewide figure and their poverty rates ranged from 10 to 15 percent. Residents also tended to stay in their homes - over 60 percent reported that they were living in the same house they were in five years earlier. Although the four counties were quite similar to each other demographically, there were differences between them. Two of the four had fared better economically, primarily because of geographical or cultural attractions - but even these better-situated counties had clear signs of a stagnated agricultural and industrial base in their towns and villages.

\section{Research Focus and Questions}

As stated, the focus of this research was on recidivist low-level female offenders living in rural-urban fringe areas. More specifically, the interest was on drug-involved women in these areas who had been arrested at least five times for minor property, public order, or drug / alcohol-related offenses.

Research questions targeted the effects of gender, coupled with place, on the individual's entry and progression in drug and criminal activity. Childhood abuse figures as a dominant theme in the literature on women and crime, as does a history of drug / alcohol addiction (Arnold, 1990; Caputo, 2008; Daly, 1992; Ferraro, 2006; Ferraro and Moe, 2003; Gilfus, 1992; 
Owen, 1998; Miller, 1986; Ritchie, 1996; Rockell, 2008). This literature, however, is generally limited to women in urban settings and it is unclear if similar dynamics exist among women outside of the city. It is, in fact, expected that, given the distinct ecological and cultural environments of these areas, the effects of gender and setting on drug activity and criminal involvement among them will vary from more urban places. In particular, it is thought that community norms about gender roles, especially those supportive of rural patriarchy and stereotypical gender stereotypes (Bouffard \& Muftíc, 2006; Campbell \& Bell, 2000; DeKeseredy, Donnermeyer, Schwartz, Tunnell, \& Hall, 2007; Carrington \& Scott, 2008: DeKeseredy \& Schwartz, 2009; Gallup-Black, 2005; Johnson, 1999; Websdale,1998), along with the unique opportunities for crime and drug use in these fringe areas, should influence not just the incidence of criminal behavior, but its nature and meaning as well.

\section{Data Sources and Methodology}

In each of the four counties, data were collected by way of intensive, qualitative interviews from four sources: the Sheriff in each county, other law enforcement personnel (including members of the road patrol and drug task forces for the county), jail staff, and women being held in the local county jails. One of the counties, like jails in many other rural localities, did not hold women within its jurisdiction, boarding them out in a jail in Monroe County, where the interviews were conducted. In addition to these in-person sources, local newspapers also were reviewed for their coverage of area women who had been arrested. This was prompted after one of the first women interviewed described the headline she had garnered in what she described as the town rag: "Sex, drugs, stolen jewelry lead to arrest of former Palmyra woman."

The sample of women interviewed was relatively small -20 women, five from each of the four respective counties who met the criteria for selection (i.e., drug involvement and five prior arrests for low-level property, drug, public order offenses). All interviews took place in the county jails where the women were housed, as detainees or under sentence. Given the sample size and the location for interviews, there are obvious issues with respect to validity, reliability, and generalizability. Concerns about validity and reliability were addressed by adhering to standards for good qualitative research (Bachman \& Schutt, 2003; Cresswell, 1998; Glaser \& Strauss, 1967; Strauss \& Corbin, 1998). Careful and consistent efforts were made in designing and conducting all interviews, attention was placed on establishing credibility with the women, and when possible, information was verified through alternatives sources, such as rap sheets, presentence investigation reports, and interviews with law enforcement/jail staff. Generalizability was not an aim of the study, which was conducted, instead, to develop rich and detailed case studies of the research participants. Case study narratives are shown in italics, with their purpose being to provide profiles of these women's experiences and to put a human face on the context of their offending behavior. All of the names used in these narratives are pseudonyms to assure anonymity. 


\section{Research Findings}

As stated, there were 20 women in the sample selected for this research. The majority or 15 were white, and five were African American. Ranging in age from 20 to 56, with an average age of 34.2 years, all but two of the women had children. The majority had been married $(n=11)$ and nine were single, never married. Except for one, all of women came from towns with populations under 10,000 or villages under 5,000 and all had grown up in working class / lower middle class homes with parents who worked in farming-related occupations, factories, trucking, restaurants, retail, or clerical positions. Most were being held / sentenced on the expected property-related offenses of larcenies and possession of stolen property, but many $(\mathrm{n}=10)$ also had DWI or possession / sales charges.

Three distinct schemes emerged from the interviews, each of which is illustrated below through excerpts from case study notes. A subtitle identifies each theme and all names presented are pseudonyms to protect the identity of key informants.

\section{(1) Family Violence}

The first theme related to the dynamics of violence is the women's familial backgrounds. This violence, however, was not the childhood physical and sexual abuse reported among so many urban female offenders. Instead, these women in the fringe were much more likely to have been tainted by the effects of violence after witnessing verbal / physical confrontations (typically alcohol-driven) between caregivers in their homes or in other settings. Also unlike what has been found among urban women in similar situations, the women of this study reported far less extended family or kin intervention with troubled families. That is, rather than moving in with an aunt or grandmother during troubled times, these women, as girls, either stayed put and learned to "put the mask on," as one said, or they left as soon as they could. There also was far less formal intervention into their early family lives, either by police or protective services.

Jennifer's dad, who was looking at a prison sentence for his $3^{\text {rd }} \mathrm{DWI}$, burnt down the family home, saying his wife, whom he had abused for years, was not going to sleep with another man in his bed.

Helen's dad was disabled and took out his frustrations on his wife and older kids. Helen eventually moved out after "hooking up with a small-town guy," followed by four of her siblings who relocated to where she was before her most recent incarceration.

And, Shirley, who grew up on the farms that used migrant workers, said these camps were like little towns - "out of the wild west - where drinking, gambling, and fighting" were the norm - especially between her parents. She, like Helen, left the area at 11 to live and work with relatives at an orange packing house in 
Florida, returning a year later to her biological father after her mother's new boyfriend became just as abusive.

Several of the women, as girls, also had stayed in the family home after their abused moms left.

Sadie - who described her childhood as "shitty, small town bullshit" - stayed with her alcoholic father until she was 14. She then moved in with her boyfriend's family.

Jenna described a childhood where her father, a crack and crystal meth addict, "left [her] places." He also threw her against a wall, after which she lost five teeth. Jenna said her mom, a "coke addict, married someone who couldn't stand [her]."

Jennifer and her brother were placed in a foster home after their mom, who free-based, left for Kentucky, where she "got clean." They returned to their father, an alcoholic, after six months. He hasn't hit her "yet" and Jennifer says she has remained in his house to this day.

Nearly three-quarters of the women also reported abusive relationships during their adult years.

Helen said that every relationship she had was an abusive one. Stacia had suffered broken ribs at the hands of her second husband; Sherry, Donna and Barb had lost teeth and suffered numerous broken bones due to the men in their lives.

Beth proudly stated that she was married to the same guy - her "knight in shining armor," she said-after 20 years. She also described this same husband, a retired state trooper, whose father and uncles were all cops, as a "Jekyll/Hyde." Beth had been the "shield for the kids," she said, when her husband's short fuse went off and he "took her down to the floor as if [she] was a suspect." Beth was now sitting in jail with a broken arm (courtesy of her husband, Bill), having been charged with a criminal mischief for tossing and lighting his golf caps and shirts in the burn barrel. He called in the report to his old barracks. After he broke her arm, her husband - Bill - told her to lie and say that she had been drinking and fell - "who do you think they'll believe," he said - "you or me?" Beth lied at first and then at the urging of her attorney spoke with a deputy about what her husband had done. That had been two weeks ago, she said, and she had heard nothing. Given the small town in which she lived (her brother's wife's sister was the DA's wife), Beth had heard, however, that the DA was encouraging her husband to "smooth things over" with her. 
In recent years, the issues of intimate partner violence in the rural setting and rural gender relations, generally, although still seriously under-studied, have received increased scholarly attention. The notion of a gemeinschaft community and all that goes with it to make for a crime and violence-free rural setting where everyone knows everyone else and there is a homogeneity with respect to community values has been challenged, especially in the context of the dramatic social and economic changes occurring in these areas. Indeed, a number of researchers (DeKeserdy, Donnermeyer, Schwartz, Tunnell \& Hall, 2007; DeKeseredy \& Schwartz, 2009; Gallup-Black, 2005) have pointed out how the isolation in more rural places and the social insularity stemming from it can preclude the kinds of constraints that a broader community can bear on a troubled family, making family violence a more likely occurrence in rural areas. These researchers, and others, also note how the nature of rural interpersonal relationships and the norms governing them- where one is very conscious of publicly airing dirty laundry -- can also exert a chilling effect on those seeking help for domestic violence. And, several, like Carrington and Scott (2008), have argued that the destabilization of the architecture of rural life has challenged rural / masculine discourses leading rural men, so challenged, to resort to violence as a largely strategic practice deployed to recreate an imagined rural gender order.

Just as obstructive to seeking or obtaining help in an abusive relationship in this setting is the patriarchal ideology inherent in rural policing, something Beth (above) certainly experienced, and Websdale (1995, p. 111) found in a relatively early ethnographic assessment in rural Kentucky:

The shared understandings, common interests, collusion, and outright misogynism of officers and batterers significantly affect the outcome of police intervention. The attitudes of rural police officers toward battered women and the battering situation as a whole tend to mirror wider rural patriarchal constructions about the social position of women...[R]ural police officers, particularly those who were raised in the rural cultural milieu, will view the family as a private and insular patriarchal unit. This may mean that police in those areas are less willing to intervene in domestics and less inclined to arrest husbands, who they feel should be in a dominant position in the family.

DeKeseredy and his colleagues (2007, p. 300) report similar findings in rural Ohio indicating that "many rural Ohio men can rely on their male friends and neighbors, including those who are police officers, to support a patriarchal status quo even while they count on these same individuals to help prevent public crimes (vandalism, burglary) which to them is acting on behalf of the common good."

\section{(2) Criminal Offending and Drug Use}

The second theme that emerged from interviews was that although gender mattered when it came to starting and getting drugs both to use and sell, place was just as, and, in some cases, 
more important when it came to being introduced to, accessing, and distributing drugs (primarily opiates and crack) in the fringe. More specifically, the two were quite intertwined and the meaning and expression of gender in the drugs and crime scenario was very much placedependent: location mattered, in other words, in shaping both the women's involvements with crime and their drug experiences relating to use and distribution.

With respect to the former, it was clear that place definitely factored into what the women did criminally and how they did it, which is discussed further below. The malls and large retail establishments dotting the fringe provided ample opportunities for shoplifting and proximity to a city with its many pawnshops and (somewhat shady) gathering places greatly facilitated the women's boosting activities. Prostitution, likewise, seemed to be situated in places where it could remain somewhat invisible or at least contained, such as highway hotels, rooming houses, and migrant farms, and, therefore, tolerated to a degree by law enforcement as a necessary evil.

The influence of place on drug-related crime and patterns of use and distribution also was evident. What appeared to be the biggest wave of local drug use / sales in these towns, especially among the young white women, was that of opiates: prescription pills and heroin. All of the users of these substances said that pills came into the towns from local residents and Rochester (hereafter referred to as the City), whereas heroin primarily originated from the City. Both substances were accessed by the women through local social networks.

How these women got started with pills generally comports with what the literature has shown (Wunsch, Nakamoto, Goswami, \& Schnoll, 2007). Most had a deep and long history with a wide variety of drugs, which some began for pain relief but many more for a sense of euphoria. For instance, many of the women talked about the boredom of small town life and wanting a different, more exciting lifestyle - one that was just 45 minutes to an hour away. Others like Jennifer (and more) seemed to be born into a "culture" where the non-medical use of prescription drugs for the relief of any and all ailments (including pain, depression, or loneliness) was seen as acceptable and less dangerous than illicit drugs (Bardhi, Sifaneck, Johnson, \& Dunlap, 2007; Inciardi \& Cicero, 2009; Leukefeld, Walker, Havens, Leedham \& Tolbert, 2007).

Most of the women in this study said they got their pills through family/friends and then known doctors in the area, the names of whom they shared with each other.

Jennifer had a long history using a variety of prescription drugs and she had an incredible depth of knowledge about the effects of each. She started using Xanax with friends when she was 16 and, then, at 17 started to get Vicodin and Lortab from her mom, aunts, uncles - the whole family. Even her grandfather had Xanax in the medicine cabinet, she said. Her family also told her of a doctor in an outlying town who would give her something. Jennifer told him she had hip problems (which she did) and panic attacks and he hooked her up with morphine patches, OxyContin, and Xanax. When she started to visit her mother 
in the Midwest, she got the names of more doctors, several of whom would mail her the prescriptions after she returned home. And, after her father died, Jennifer visited his doctor for her pills, which she continued to do until she went to prison, with her husband, for grand larceny.

Others became more enterprising criminally and used their places of employment to pocket psychotropic drugs, like Jessica and Cindy, who were CNAs and took their elderly patients' drugs. Many of the women also spoke of trading prescriptions - calling one another, offering someone what they had for what they could get from the other. As stated earlier, "scripts" (i.e., prescriptions) also were making their way into the towns by way of the City.

Rebecca said her boyfriend met a guy from the City while in jail. He was a crackhead, she said, and would sell her husband their scripts - Percoset, methadone, Vicodin, OxyContin - for a good price. Several other women mentioned buying scripts off of individuals in the City who they assumed had stolen them from others, homes, or pharmacies.

A good number of the women eventually added heroin to their medicine cabinet or transitioned from the use of pills to heroin. Reasons for this transition varied. For some, the family and medical sources of pills eventually shut down, and heroin became the best substitute. For others, heroin was more accessible and cheaper - especially in the City.

Jennifer said she couldn't seem to find her "scripts" anymore - "everyone here is getting so addicted to them," she said - so she took up the offer of a guy she worked with to go the City and get some heroin.

Although most of the women got their heroin from the City "because they knew better," as Donna said, there was some presence of it in the towns courtesy of what Furst and his colleagues (2004, p. 434) have referred to as "jugglers", heroin-dependent users who begin selling heroin as a means to defray the cost of their habits.

Jessica and her ex-boyfriend were jugglers - who made the trip to the City to buy their heroin - some of which they'd sell to those in town who did not have access to or the inclination to seek out cheaper product in the City.

Jessica and her ex also appeared to have engaged in what Furst and his colleagues called "tricking"(p. 435) - deceiving others into using heroin by saying it was something else - hash, cocaine, etc. She divulged this at her first interview - referring to one town as "junkie town -because of me and my ex." Both of these criminal activities - "juggling and tricking" - were obviously facilitated by the small town environment of the women and the importance of local social networks in their worlds. 
The women generally began their heroin use by sniffing. However, all but one was now injecting. Reasons given for transitioning to "the needle" included the immediacy of the high ("the rush") the women said they experienced, the reported expense of snorting, the avoidance of dope sickness, and the attraction / excitement of the lifestyle, especially when compared with the routine of small-town living (Draus \& Carlson, 2006). For some of the women, the use of heroin also was a way to combat a "good girl" image and identity so socially important in their rural context (McCoy, McGuire, Curtis, \& Spunt, 2005). Again, becoming a "gangster", if you will, or a self-injecting heroin user with the criminal lifestyle that it connoted was very attractive to these women.

This was clearly the case with Rebecca, Sadie and Beth. Rebecca was very little girlish physically - and she hated that. Her father called the cops on her at $16-$ she was so intoxicated that he wanted to get her to the hospital. While in the $E D$, Rebecca kicked a nurse in the face, shattering her nose. She was in jail now for violating a restraining order - having punched her husband in the face. Sadie left home at 14 - because of all the "small town bullshit." She moved to Rochester and then spent five years going back to her small town to do painting jobs that gave her the opportunity to steal from home-owners. When we started talking about her alcohol/drug use, Beth said, "I was a good girl -- I went to Catholic schools. At 18, I didn't want to be good anymore and started big time."

More important than rebellion and resistance in explaining their use of heroin, however, was what McCoy and her colleagues (2005) called the prevailing cultural logic in this society "which promotes the idea of a pharmacological 'fix' for whatever causes discomfort in one's life" (p. 835).

Sadie talked about the pains of everyday life. And, Jennifer, who lost a baby and her father within months of each other, said that when she used Xanax, she "walked on clouds, in the sunshine, and didn't feel. I haven't felt in years," she said, "and I don't want to start."

Relevant to the women's use of crack was Draus and Carlson's (2007) ethnographic study of crack initiation and use among 50 individuals in three rural counties located 40 minutes from Dayton, Ohio, a setting somewhat comparable to that of the present study. One of the first observations these authors make relates to the fluid and dynamic movement of individuals, substances, and accompanying behaviors between large and small population centers. And, with respect to the initial use of crack, most of the individuals in their study were introduced to the drug through a variety of social interactions, as well as criminal involvements, in the City outside of their hometowns. These included running away to, partying in, or working/traveling in the City (p. 89). The women in this study reported similar initial experiences with crack: 
Michelle, who said she did "everything but shooting" left home at 12, described herself as a "quiet girl" who drank amaretto and rum to take herself "out of character." Although alcohol "started" her, it was crack that "got" her-and, she said, "it was available on every corner of the City."

Sadie moved away from her alcoholic father's house at 14, staying with her boyfriend in the City for three years. While there, she waitressed and bartended, starting crack at 15, then heroin at 20, to escape the "pain of everyday life."

Shirley and her abused mother moved to Florida to pick oranges when Shirley was 11. When Shirley came back to the area, she was introduced to crack by a guy from the City, whose drugs she started to sell from her apartment in town. Donna liked to party as a teenager at an "after hours joint in the City." Moving there at 17, she began a nearly 30 year career of stripping, prostituting, and running a crack house. Now 45, Donna had returned to the area with a guy from the City to work in the vineyards.

Virginia described herself as a "military brat" who was always running away from whatever base where her father was posted. By 15, she was a selfdescribed alcoholic living in the City where crack was plentiful. At 20 Virginia was back in the small town of her birth where "everyone hated her," she said, because of her "Black boyfriends."

The influence of gender and place was clearly seen in how the women accessed crack dealers in the City of Rochester for their own personal drug use or to buy for selling purposes, establishing a local criminal enterprise. This was usually done in one of three ways. A good number of the women had been set up by male family members or friends from Rochester.

Helen was typical. Now 42, her "best years," she said, were her 30's, when her three brothers and their friends from the City would just hang out at her house, bringing an array of drugs and cash for her to sell locally. Shirley was even more resourceful. She and her boyfriend, also set up through friends in the City, would follow the migrant workers in her town (Shirley, in fact, had grown up on a camp) over the season to different farms, selling to them from motels or rooming houses in the area.

Other women would make the trip to the City themselves, often accompanied by men, to buy their drugs. And, then there were those who developed romantic relationships with men in the City that were probably more instrumental than emotional.

Ginny is a good example. She was in custody for using her truck to help a friend steal copper piping for sale in the City as scrap. She claimed that she maintained "two boyfriends in Rochester - one for pot, the other for crack." 
Ginny had spent the past year selling and trying to make a name for herself in the country. "I'm addicted to the lifestyle," she said. "It makes me feel powerful - not many people can turn $\$ 50$ into \$500.”

Ginny, thus, took criminal advantage of place, stealing material of value from neighbors that she later unloaded or sold in the City. This criminal use of place is even more dramatically seen in the behavior of many of the other women in this study who moved between rural and urban spaces, as Draus and Carlson (2007, p. 96) found, to serve as "intermediaries, runners or connections" for fostering the diffusion of crack cocaine and related behaviors from the City to the country.

Elsie was one of those intermediaries in this study. Born to the sole black family in her very small town, she had moved back and forth to Rochester and the town where she now lived, which she called Peyton Place, for over 20 years. In her late 40s, she had settled back down permanently in the latter and used her connections in Rochester to use and sell crack out of her house. Donna, on the other hand, was an émigré to the country. She had left Rochester with one of her dates after her self-described crack house was robbed. Donna was now moving from town to town and man to man in the country, while making frequent trips back to the City, always with others, to buy crack from the dealers she knew. Helen also was an émigré, having moved to Clyde, NY from Brooklyn 22 years ago. She had been a runner for crack, she said, and for three years made the 45 minute trip to Rochester every day. It was easy, she claimed. "You don't get caught in the cities. People out here have time to catch you. And, if you don't belong - they know."

Draus and Carlson (2007) also note how patterns of crack use and distribution were modified by the context of the small rural town, with local social networks providing the primary means by which these patterns were transmitted and translated. They observe, "small towns present a different social context than that which is found in large cities, especially in terms of the limited number of available venues for illicit behavior ... [and] the interconnectedness of social networks..." (p. 100). Both of these elements related to the context of using and distributing crack were unique in this study's rural-urban fringe areas.

Looking first at the venues for use, the women in this research, like those in the above authors' work, indicated that the most popular venues for use and distribution in the fringe included houses, cars, bars, and hotels. The houses referred to were not the crack houses associated with urban use, but rather the private residence of another trusted user, a safe place to go - out of sight - where one could get high and party, even if you had to share what you had with the home owner. 
Barb would use one of her aunt's houses using her drugs as a "door fee" or cover charge. Elsie and Shirley, women whose children were grown and gone, opened their houses to users. And, Beth had an enclosed back porch on her dairy farm where she and others would use.

Cars were a second popular venue for use. Many of the women made the unfortunate mistake of using the crack they picked up in the City on the long (boring) trip back to the country. Many also would spend hours driving around the country back roads getting high. Just as popular as cars were the many rather dingy, run-down motels / hotels just outside of or in commercial areas of these towns where the women used their drugs. They also mentioned other outdoor places as venues for where they used their drugs, like the woods or at the lake.

Brown and Smith (2006) found similar patterns of outside places / spaces for cocaine use among their sample of 30 rural African American women. And, their interpretation for why the women used these out-of-home places had relevance here, as well. Based on statements made to them, these researchers argue that "the psychological factor that most clearly seemed to drive the choice of drug-use place centered on the maternal desire to protect children from observing druguse behavior (theirs and others')" (p. 196). Although the women in the present study expressed similar sentiments about when and how they used, most, because of their presence in jail, had lost custody of their kids to mothers, grandmothers and husbands. And, all were now saying that they would do what they had to do to get those kids back.

Looking secondly at the importance of social networks for the distribution of crack, the most frequent expressions voiced by these women were - "word of mouth," "you know who to go to," and "you just know who's doing what." These expressions applied to both the people and locations - who to go to and where to get the drugs you were looking for. Not surprisingly, there were a number of bars in these counties where drugs, while not being used at the bar, could be easily obtained.

Jennifer spoke of the bar where she worked \& said you just have to say crack and you will get it. Jennifer was a former Xanax user, now heroin-addicted, who used to trade her Vicodin scripts with guys at the bar, veterans and athletes, for Xanax.

In addition to particular bars, which the women did not hesitate to name, were the rooming houses, private houses, and motels where crack could be purchased.

\section{(3) The Rural-Urban Fringe}

The third and final theme from this research should be clear at this point. It has to do with the permeability of the border between these fringe areas and the City and the constant movement of people and behaviors between and across it. 
As stated earlier, this project began with somewhat of an urban bias looking for the traffic of City women into the hinterland to sell drugs, which had been seen, by this researcher, as a resourceful strategy for creating safe opportunities to carve out a niche of the drug market for themselves. The women and officials were questioned about this claim and nearly all denied its veracity. Instead, what was found was what so many others have shown to be the case in more populated areas of extreme poverty and structural violence - that the informal drug economy, even in the different social and economic contexts presented by these fringe areas, continues to be gender stratified and hierarchically controlled by men (Maher \& Hudson, 2007). That is, at times, men from the City would access these fringe markets by setting local women up in rooming houses, motels, or their private residences to sell drugs. But, it was the men, and not women from the City, who controlled this business.

Once this notion of the fringe being an insular colony for exploitation was discarded, it was clear that what existed was an incredible movement of people, goods, services, and drugs through these rural-urban areas. There were many structural, economic, and institutional forces at play here in directing or facilitating this movement. And, it is suggested that these many forces are best understood as being indicative of the social and cultural changes typically associated with the antecedents of social disorganization theory, such as population turnover, the proportion of single parent households, and poverty ( Barnett \& Mencken, 2002; Bouffard \& Muftic, 2006; Donnermeyer, Jobes, \& Barclay, 2006; Tunnell, 2006). Indeed, as Donnermeyer and his colleagues (2006: 205-206) point out, research has "consistently found that social and cultural factors account for more crime in rural areas than in metropolitan areas [indicating that] social factors have much more direct effects in rural areas because their disintegration implies the loss of community." And, a prominent contributor to these changes, according to the above-cited authors, is the "growing interdependence of rural and urban areas, as well as... a relationship of dependency, to some extent, [of rural areas] on urban areas" (206).

Although this research cannot provide any "hard" empirical support for the above assertions, it did yield suggestive impressions of their influence from the women and law enforcement personnel interviewed. The women's previously discussed drug activity certainly is indicative of the somewhat symbiotic relationship between these fringe areas and the City. Also suggestive were the dynamics of the property and public order crimes the women committed. For instance, among the women who were boosters (i.e., those who stole to resell or gift to others), it was clear that the "wal-marting" (Tunnell, 2006) of the region had created new and productive opportunities for criminal behavior. Several of the women mentioned an unnamed woman in the area who allegedly ran a ring of boosters that traveled between the many Walmarts stretching across the different towns, stealing from one and returning to others. Many more indicated that they took jobs at Walmart for criminal purposes: some reported charging unwitting customers for gift cards not purchased and others said they worked with friends who never paid for merchandise taken. 
The many malls dotting the western and central regions of the State also provided ample opportunities for boosting. A number of women also reported larcenies committed in the City and selling or gifting their wares in the small towns of the fringe. And, several said they stole products (such as copper piping, chain saws, wood stoves) in the towns which they resold in the City.

The women's involvement in prostitution also was reflective of the social and cultural changes taking place in their communities, as well as the interdependence between the country and city. A number reported servicing the migrant farm labor camps in the area (all of whom seemed to be well known to law enforcement). Several spoke of using rooming houses in the towns or motels lining the highways outside of them, and many more seemed to travel back and forth to the City for this purpose. One town, in particular, was said to house many of these women and high rates of drug activity. This town, according to both law enforcement and the women, was claimed to be a mirror-image of the City, containing many individuals who had left the slums there and now lived in rural areas that were as impoverished. Donnermeyer and his colleagues (2006, p. 210) cite this cross-migration between urban and rural slums as an "especially virulent form" of population transience related to social disorganization in rural communities.

Although the main source of data for this study were the women interviewed, the researcher also met with many law enforcement personnel in each county to learn their impressions of women and crime in their jurisdictions. As one might expect, a number of Sheriffs evinced an almost "border patrol" mentality about their towns. That is, discussion often centered on their need to take a proactive, order maintenance stance with respect to the flow of drugs and crime from the City into their towns. Several claimed the towns were experiencing negative repercussions of Rochester's get tough, zero tolerance policies or that crime was being shunted in their direction.

Concerns also were expressed about the presence of prisons in their jurisdictions - that with the relocation of prisoner families to rural towns, crime and drug activity would surely increase. Although data supporting these claims were not provided, it is not possible, in the present study to discount them completely. Moreover, it certainly seemed likely that beliefs or perceptions such as these were influencing law enforcement activities in the towns. The women interviewed were very vocal about these border enforcement activities of local law enforcement. They were "ridiculous", they said, and particularly tough on women, who, many claimed, were less likely to be assigned to a drug court or be diverted to treatment from the system than in the past. It certainly was clear that the jails in these areas, which usually had boarded out what few females they had to the larger city detention facility and penitentiary, had changed dramatically in terms of their gender composition. 


\section{Discussion}

The life experiences and patterns of crime and drug use among the women in this study were quite different from those that characterized the urban women previously profiled by the author (Rockell, 2008). And, these differences are best understood by referencing the influences of place or locality on the lives the women had lived and were living either in the City or the urban rural fringe.

For instance, among the urban women previously studied drug use and crime were very much rooted in familial relationships and communities of residence. These women were exposed to drug use and other criminal behaviors early on in their lives through family and social networks in their neighborhoods. As children, they often committed crimes with those in their neighborhoods, as well as siblings and cousins, and later, as adults, they accessed these same social networks to obtain drugs and assistance in boosting or other criminal activities. Drugs were readily available to these women and part of a lifestyle that encouraged, supported, and facilitated criminal involvements.

In contrast, the very lives of women in the urban-rural fringe seemed "fringe-like." That is, they, as individuals, did not quite fit in their towns. Moreover, the social and cultural changes occurring in their communities were very much mirrored in the women's drug and criminal experiences. For example, drug use among these women seemed linked to feelings about place or more specifically the boredom they associated with their context, especially when compared to the seemingly more exciting life available just an hour away. Many also advanced into the drug lifestyle to combat what they saw as their "good girl" image born of the country. In addition, personal effort and persistence was necessary to obtain drugs: they had to be able to access certain marginal places or people in their towns or they had to travel to the City where they often connected with acquaintances met in jail. Moreover, these women evinced an interesting and keen understanding of the somewhat symbiotic relationship between the City and the fringe: not only did they recognize the market for criminal proceeds in the former, they also knew full well to avoid (if possible) criminal activity in the latter, where law enforcement knew everyone and had a great deal more time on their hands than their partners in the City.

In concluding this article, it appears, as was stated above, that the research findings here are best understood when contextualized and analyzed within the theoretical framework of social disorganization, which, "because it is a place-based theory...can incorporate both macro change and local context" (Donnermeyer, Jobes, \& Barclay, 2006, p. 206). Indeed, it is argued that the rural-urban fringe studied here represents a place where the criminal behaviors directed at and committed by women are reflective of the unique social, economic, and cultural features that characterize the border between city and country. Moreover, it must be recognized that this place

presents a complex ecological setting with elements indicative of both social organization and social disorganization. 
Reflective of the social organization of the fringe is the incidence of and personal / public reactions to domestic violence among the women. These women, as children, witnessed violence within the family that was experienced in a very different normative setting from their urban counterparts. It was, in a sense, privatized or insulated within the family unit, not discussed with kin and rarely reported to the police or other public officials. When experienced as adults, the same norms about family privacy and male supremacy remained operative. In fact, these women were marginalized and made invisible in both their homes and their towns: they did not see themselves as victims of a crime, nor did the police or other law enforcement officials who by responding in a manner to "smooth things over" merely reinforced the patriarchal organizing principles of their society.

At the same time, the crimes committed by these women, which were primarily property and public order offenses, must be situated ecologically in the structural and cultural dynamics of a place witnessing significant re-organizaiton of its social structure. The economies of these once rural towns were no longer based in agricultural undertakings and there was a growing dependency on the nearby cities and the state (in the presence of its prisons), and large nationwide corporations for jobs. One result was a greater mobility of the population from local communities to adjacent cities or distant State correctional facilities for jobs, undermining the familial/social integration of towns. Indeed, nearly all of the women had spent time in the City and committed crimes there, where they said you were far less likely to get caught as most had been in multiple towns in their county.

Another repercussion was the creation of new criminal opportunity structures in these areas for residents, such as those presented by nationwide chains like Walmart and the sprawling suburban malls across the region. An even more distressing implication of the increased dependency between country and city was "the cross-migration between particular rural and urban slums involving streams and counter-streams of highly disenfranchised people with high rates of crime" (210). This was discussed earlier in reference to a particular town with a large percentage of minority residents, which the local Sheriff dismissed as a "mirror-image of the City." Many women in this town were said to move back and forth to the City for the purpose of prostitution while at the same time transporting crack into the area.

The introduction and influence of non-traditional values and beliefs presented an equally potent source of disorganization in these areas. It was, in fact, the movement of these cultural elements into the fringe from the City and beyond by way of the media and technology that provided the bases for the women's drug use. For many, the use of drugs provided an escape from the boredom of their small town existence. For others, becoming involved with drugs and the lifestyle associated with their use enabled the women to challenge and re-create traditional gender identities rooted in a patriarchal social structure. And, then there were those who saw their illicit use of prescription medications as being similar to the larger cultural logic in American society, supportive of the ingestion of drugs for all and any physical, psychological, or emotional ailment. 
Prior to the present study, this author pursued a research agenda intended to make visible the actors and institutions rarely addressed or even acknowledged by criminal justice scholars. Thus explains her long-standing interest in low-level female offenders and jails. She now adds to that agenda a setting with places of great, yet unrecognized, diversity, which remain unseen despite the significant cultural, social, and economic changes witnessed by their residents, and a growing interdependence with the urban worlds they border. The unanswered questions and issues raised by the present research are far too numerous to list in this particular context. However, it is certain that the author will continue her journey into these unique social spaces and hopefully contribute something of worth to a growing interest and involvement among scholars in non-urban criminological research.

\section{Endnote}

${ }^{1}$ All of the data in the following two paragraphs are derived from U.S. 2010 Census Quick Facts at http://quickfacts.census.gov/qfd/index.html. 


\section{References}

Arnold, R. (1990). Processes of victimization and criminalization of black women. Social Justice, 17, 153-166.

Bachman, R. \& Schutt, R. (2003). The practice of research in criminology and criminal justice. Thousand Oaks, CA: Sage.

Barkan, S. \& Bryjak, G. (2009). Myths and realities of crime and justice: What every American should know. Sudbury, MA: Jones and Bartlett Publishers.

Barnett, C. \& Mencken, F. (2002). Social disorganization theory and the contextual nature of crime in nonmetropolitan counties. Rural Sociology, 67, 372-393.

Bouffard, L. \& Muftíc, L. (2006). The "rural mystique:" Social disorganization and violence beyond urban communities. Western Criminology Review, 7, 56-66.

Brown, E. \& Smith, F. (2006). Place and space: The where and why of drug use location among African American women. Journal of Family Nursing, 12, 185-200.

Campbell, H. \& Bell, M. (2000). The question of rural masculinities. Rural Sociology, 65, 532546.

Caputo, G. (2008). Out in the storm: Drug-addicted women living as shoplifters and sex workers. Boston: Northeastern University Press.

Carrington, K. \& Scott, J. (2008). Masculinity, rurality and violence. British Journal of Criminology, 48, 641-666.

Cresswell, J. (1998). Qualitative inquiry and research design: Choosing among five traditions. Thousand Oaks, CA: Sage.

Daly, K. (2002). Women's Pathways to felony court: Feminist theories and problems of representation. Review of Law and Women's Studies, 2, 11-51.

DeKeseredy, W., Donnermeyer, J., Schwartz, M., Tunnel, K. \& Hall, M. (2007). Thinking critically about rural gender relations: Toward a rural masculinity crisis/male peer support model of separation/divorce sexual assault. Critical Criminology, 15, 295-311.

DeKeseredy, W. \& Schwartz, M. (2009). Dangerous exits: Escaping abusive relationships in urban America. New Brunswick, New Jersey: Rutgers University Press.

Draus, P. \& Carlson, R. (2006). Needles in the haystacks: The social context of intiation to heroin injection in rural Ohio. Substance Use \& Misuse, 41, 1111-1124. 
Draus, P. \& Carlson, R. (2007). Change in the scenery: An ethnographic exploration of crack cocaine use in rural Ohio. Journal of Ethnicity in Substance Abuse, 6, 81-107.

Ferraro, K. \& Moe, A. (2003). Women's stories of survival and resistance. In B. Zaitzow\& J. Thomas (Eds.), Women in Prison: Gender and Social Control (pp. 65-93). Boulder, CO: Lynne ReinnerPublsihers, Inc.

Ferraro, K. (2006). Neither Angels Nor Demons: Women, Crime, and Victimization. Boston: Northeastern University Press.

Furst, R., Herrmann, C., Leung, R., Galea, J, \& Hunt, K. (2004). Heroin diffusion in the midHudson region of New York. Addiction,99, 431-441.

Gallup-Black, A. (2005). Twenty years of rural and urban trends in family and intimate partner homicide: Does place matter? Homicide Studies, 9, 149-173.

Gilfus, M. (1992). From victims to offenders: Women's routes of entry and immersion into street crime. Women and Criminal Justice, 4, 63-89.

Glaser, B. \& Strauss, A. (1967). The discovery of grounded theory. Chicago: Aldine Publishing Company.

Inciardi, J. \& Cicero, T. (2009). Black beauties, gorilla pills, footballs, and hillbilly heroin: Some reflections on prescription drug abuse and diversion research over the past 40 years. Journal of Drug Issues, 39, 101-114.

Johnson, N. (1999). Nonmetropolitan sex-role ideologies: A longitudinal study. Rural Sociology, 64, 44-65.

Leukefeld, C., Walker, R., Havens, J., Leedham, C., \& Tolbert, V. (2007). What does the community say: Key informant perceptions of rural prescription drug use. Journal of Drug Issues, 37, 503-524.

Maher, L. \& Hudson, S. (2007). Women in the drug economy: A metasynthesis of the qualitative literature. Journal of Drug Issues, 37, 805-826.

McCoy, K., McGuire, J., Curtis, R., \& Spunt, B. (2005). White chicks on dope: Heroin and identity dynamics in New York in the 1990s. Journal of Drug Issues, 35, 817-841.

Miller, E. (1986). Street women. Philadelphia: Temple University Press.

Owen, B. (1998). In the mix: Struggle and survival in a women's prison. Albany: State University of New York Press.

Ritchie, B. (1996). Compelled to crime: The gender entrapment of battered black women. New York: Routledge. 
Rockell, B. (2008). Women street hustlers: Who they are and how they survive. Washington, DC: American Psychological Association.

Sharp, J. \& Clark, J. (2008). Between the country and the concrete: Rediscovering the rural urban fringe. City \& Community, 7, 61-79.

Strauss, A. \& Corbin, J. (1998). Basics of qualitative research: techniques and procedures for developing grounded theory. Thousand Oaks, CA: Sage.

Tunnell, K. (2006). Socially disorganized rural communities. Crime Media Culture, 2, 332-337.

Websdale, N. (1995). An ethnographic assessment of the policing of domestic violence in rural Eastern Kentucky. Social Justice, 22, 102-122.

Wells, L. \&Weisheit, R. (2004). Patterns of rural and urban crime: A county-level comparison. Criminal Justice Review, 29, 1-22.

Wunsch, M., Nakamato, K., Goswami, A., \&Schnoll, S. (2007). Prescription drug abuse among prisoners in rural southwestern Virginia. Journal of Addictive Diseases, 26, 15-22. 